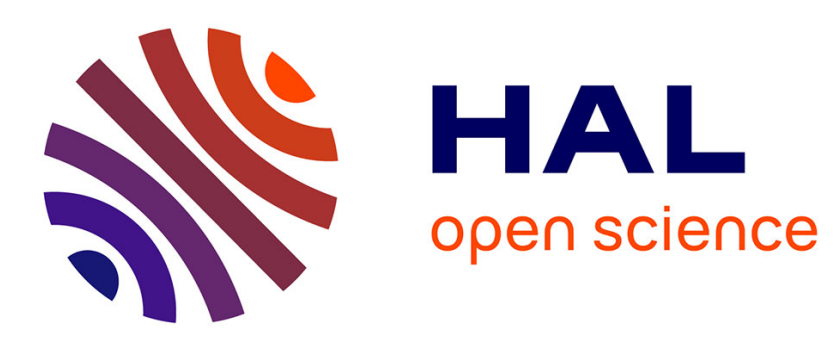

\title{
Primate cranium morphology through ontogenesis and phylogenesis: factorial analysis of global variation
}

\author{
Nicole Petit-Maire, Jean-François Ponge
}

\section{To cite this version:}

Nicole Petit-Maire, Jean-François Ponge. Primate cranium morphology through ontogenesis and phylogenesis: factorial analysis of global variation. Journal of Human Evolution, 1979, 8 (2), pp.233-234. 10.1016/0047-2484(79)90089-7 . hal-00507112

\section{HAL Id: hal-00507112 \\ https://hal.science/hal-00507112}

Submitted on 9 Feb 2011

HAL is a multi-disciplinary open access archive for the deposit and dissemination of scientific research documents, whether they are published or not. The documents may come from teaching and research institutions in France or abroad, or from public or private research centers.
L'archive ouverte pluridisciplinaire HAL, est destinée au dépôt et à la diffusion de documents scientifiques de niveau recherche, publiés ou non, émanant des établissements d'enseignement et de recherche français ou étrangers, des laboratoires publics ou privés. 
Primate Cranium Morphology through Ontogenesis and Phylogenesis, Factorial Analysis of Global. Variation

\section{N. Petit-Maire}

Laboratoire de Géologie du Quaternaire, C.N.R.S., Centre Universitaire de Luminy, 13288 Marseille Cedex 2, France

\section{J. F. Ponge}

Laboratoire d'Ecologie générale, Muséum d' Histoire Naturelle, Brunoy, France

Factorial analysis of Primate cranial morphology describes variation of the Order in postnatal growth, and shows the positions of some fossil specimens relative to present species.

Cranio-facial variation in living Primates has been examined by factorial analysis of measurements of individuals of all ages and both sexes, belonging to all taxonomic groups. Most extant species are presented, but the sampling, based on measurement of West European collections, is quite irregular and in particular there are few immature skulls. However, the field covered-the whole primate order-is so great that sorting results have been good.

The 12 variables used were chosen by discriminant analysis out of 45 classical measurements (PetitMaire, 1972); they are listed on Figure 1. The multivariate analysis used was the "Analyse des Correspondances" (Benzecri et al., 1973; Lebart \& Fenelon, 1973), slightly modified to clarify the position of individuals near the extremes of each variable, we added to each parameter location its inverse value, the number of variables being thus doubled.

As regards missing data in incomplete crania, we adapted Benzecri's (1973) method. Each missing measurement is replaced by the product of the line and of the column in the initial data matrix; the matrix is then analyzed. From factors extracted (two to four are in general available), the data are reconstructed by the usual 
formula and the resulting new matrix is then analyzed. By iteration the process is convergent and gives a final value corresponding to the best possible one in the light of the observed measurements.

In the present study, there is little error deriving from this procedure, since a minimal number of three or four measurements is often sufficient to characterize a cranium and we already have, from analysis of complete crania, a quite precise idea of how the taxa vary. An additional safeguard was incorporated in the procedure itself: those variables in which missing data occur have been positioned as supplementary variables so as to reduce error in convergence. The method is satisfactorily tested by comparing complete and incomplete crania in the same species: the results are identical.

Figure 1 presents the first two factorial axes; they account for $97.5 \%$ of the total variation, leaving out only individual variations of no taxonomic interest. Cranial size is strongly weighted on axis 1 , while axis 2 mostly describes gradients of relative facial development. The graph is sufficiently clear but there are a few points to be noted:

(i) The analysis deals only with cranio-facial biometry, and excludes some important descriptive traits such as details of the bulla or of dental morphology.

(ii) Living Primate populations are described in terms of their postnatal ontogenesis, the "lines" and "branches" appearing on the graph are growth curves and not a phylogenetic tree, although it may look like one and perhaps be related to one. The branching of the taxonomic units from a basic shape, common to all Primates (and Insectivora probably) is logical, considering Von Baer's, Cope's and De Beer's laws (Cope, 1888; De Beer, 1958). Important variations in shape are possible only above a certain size.

(iii) From this graph, one cannot say if the original basic shape is of Prosimian, Simian or "neutral" type, although the last hypothesis is the most logical, considering the very early separation in all branches (except, maybe, Pongids and Hominids).

(iv) The position of Daubentonia, at the fringe of Cercopithecoidea, is due to its globular skull and is a reminder of the limits of the analysis (rodent characters are not taken into consideration). Moreover, no young individuals were available to see the early branching off of species.

(v) Hylobatidae are clearly excluded from Pongidae, and tend towards the Cercopithecidae: in their 
case, data on post-cranial skeletal morphology and paleontological material (Ankel, 1965) are not contradictory.

(vi) Homo (the sample includes Australian, European, Melano-African, Mongolic and Tasmanian crania) is defined among the order as the species with the longest growth time and with its own characteristic axis nearly parallel to factorial axis 2 (cranial development).

(vii) There appears frequent hypermorphosis in the evolution of the Order, and no evidence for the splitting of Australopithecus into several species, considering the extent of species variation in the closest living groups.

We hope this synthetic graph will help both zoologists and palaeontologists in their taxonomic research: although only quantitative and limited to crania, it shows once more the importance of the biological concept of species (Mayr, Huxley) and the need to consider the evolution of a phylum, no longer as a succession of types but as a progressive displacement of variation in fossil populations.

\section{References}

Ankel, F. (1965). Der Canalis sacralis als Indikator fur die Lange der Caudal region des Primaten. Folia Primatologica 3, 263-276.

Benzecri, J.P. et al. (1973). L'Analyse des données, Vol. II, L'Analyse des correspondances. Paris: Dunod.

Cope, E.D. (1888). On the origin of genera. Proceedings of the Academy of Natural Science of Philadelphia.

De Beer, G. (1958). Embryos and Ancestors. Oxford: Clarendon Press.

Lebart, L. \& Fenelon, J.P. (1973). Statistique et informatique appliquées. Paris: Dunod.

Petit-Maire, N. (1972). Evolutive trends and comparative ontogenesis in Primate cranium. Journal of Human Evolution 1, 17-22. 


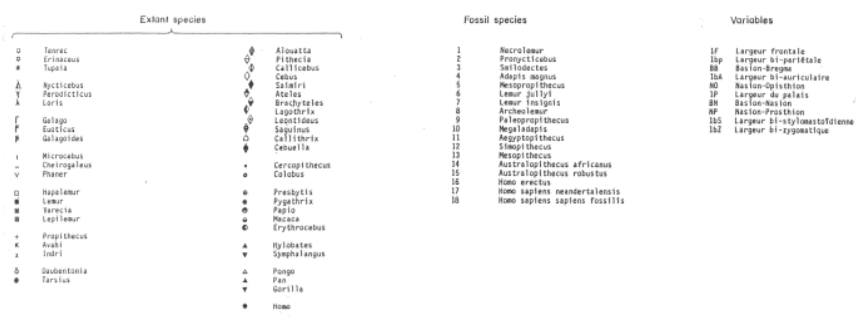

Figure 1 (foldout). “Analyse factorielle des Correspondences”. (First two factorial axes) Primate crania postnatal growth. 